\title{
THE CILIARY FEEDING MECHANISM OF THE CYPHONAUTES LARVA [POLYZOA ECTOPROCTA]
}

\author{
By D. Atkins, D.Sc. \\ From the Plymouth Laboratory
}

(Text-figs. $\mathrm{I}-7$ )

The cyphonautes larva found in certain ectoproct Polyzoa is considered to be most probably a primitive larval form, which has been lost in viviparous species, the larvae of which are degenerate in varying degree and settle within a short time. The cyphonautes is truly planktonic and has a free swimming life of some length — of 2 months according to Marcus (I940, p. 334)—and unlike the other known larvae of the group, has a functional alimentary canal. It obtains its food by maintaining a continuous current of water through the mantle cavity or vestibule, its ciliary mechanism being organized on a plan somewhat resembling that of bivalve molluscs, with an inhalant and an exhalant chamber with interposed ciliary ridges bearing current-producing and food-conveying cilia. As in lamellibranchs the organ creating the water and food currents is separated by a considerable interval from the mouth. In lamellibranchs this interval is bridged by the palps and the oral grooves; in the cyphonautes by the ciliated tract of the funnel. The cyphonautes being a larval form of probably archaic character its method of feeding is of particular interest.

For the study of the ciliary feeding mechanism the larva of Membranipora membranacea (L.) (=Nichtina telacea (Lamarck)) was mostly used, rather than that of Electra pilosa L., because of its greater size and transparency. The former larva attains a basal width of $840 \mu$, while the latter reaches only $440 \mu$ (see Atkins, 1955). For the indication of currents Chlorella stigmatophora, Peridinium trochoideum and Phaeodactylum tricornutum Bohlin were used. They were most kindly supplied by Dr M. Parke.

Larvae for sectioning were narcotized with magnesium chloride, a few drops of $7 \%$ in tap water being added at intervals to a watch-glass of sea water. The narcotized larvae were first dropped into Io \% formalin for about a minute, and then transferred to a modification of Bouin's fixative (saturated picric acid in $90 \%$ alcohol, 2 parts; saturated corrosive sublimate (water), 3 parts; $40 \%$ formalin, I part; glacial acetic acid, 2 parts). In this way larvae were fixed extended. If dropped directly into the second fixative they were found to contract strongly even after being well narcotized. Sections were cut 4,6 and $8 \mu$ in thickness. 
It was not until my paper had been written that I had an opportunity of seeing the beautifully detailed and illustrated paper by Kupelwieser (1905-6) on the histology and metamorphosis of the larva of Electra pilosa.

\section{The Structure of THe Cyphonautes LARva With SPECIAL Reference to the Mantle Cavity or Vestibule}

The general structure of the cyphonautes larva is well known (Fig. I). The body is enclosed in a triangular bivalve shell, chitinoid and transparent, and is strongly compressed laterally. The valves are approximated by an adductor muscle, composed of smooth fibres, which before the adhesive organ develops has the form of an arc; a muscular loop slung round the adductor attaches it to the body wall over the gut.

The apex of each valve is truncated and grooved for the reception of the apical organ, which bears a tuft of long cilia, sensory in function.

The pallial lobes enclose a large mantle cavity or vestibule. The external epithelium between the anterior and posterior edges of the valves in life is minutely papillate, with protoplasmic protrusions. It bears ciliary tufts and long cilia, which are probably sensory in function, for they have a slow and irregular beat.

Basally the valves gape and the pallial lobes are here thickened and heavily ciliated, forming a complete ring or corona in very young larvae according to Prouho (I892, p. 6I6). In older larvae the cells of the middle region are reduced in height and bear short, inconspicuous cilia, as first noted by Claparède (I863, p. I08). Thus the corona-the swimming organ of the larva -is divided into separate anterior and posterior regions.

The anterior portion of the corona borders the entrance to the pyriform organ, or, in young larvae, the invagination which is the precursor of that organ. At each end posteriorly it is sharply recurved, running inwards and anteriorly toward the glandular region of the pyriform organ.

The posterior portion of the corona borders the exhalant aperture and the strong beat of its cilia, from the apex toward the base of the shell, contributes to the exhalant current.

Reduction of the cilia in the middle region, or inhalant aperture, is no doubt to prevent their action from interfering with the inhalant current. If present in full development, the current produced by them would be in direct opposition to the inhalant current. In young larvae of Electra pilosa, with basal width of shell about $\mathrm{I} 60 \mu$, the inhalant aperture is large compared with the anterior region of the corona.

Two ciliated lobes projecting toward each other across the mantle cavity, separate the middle or inhalant aperture from the exhalant aperture. They are directed slightly downward, beyond the ciliated corona, and posteriorly. Each lobe is continued as a ciliated ridge, ascending in an arc across the 


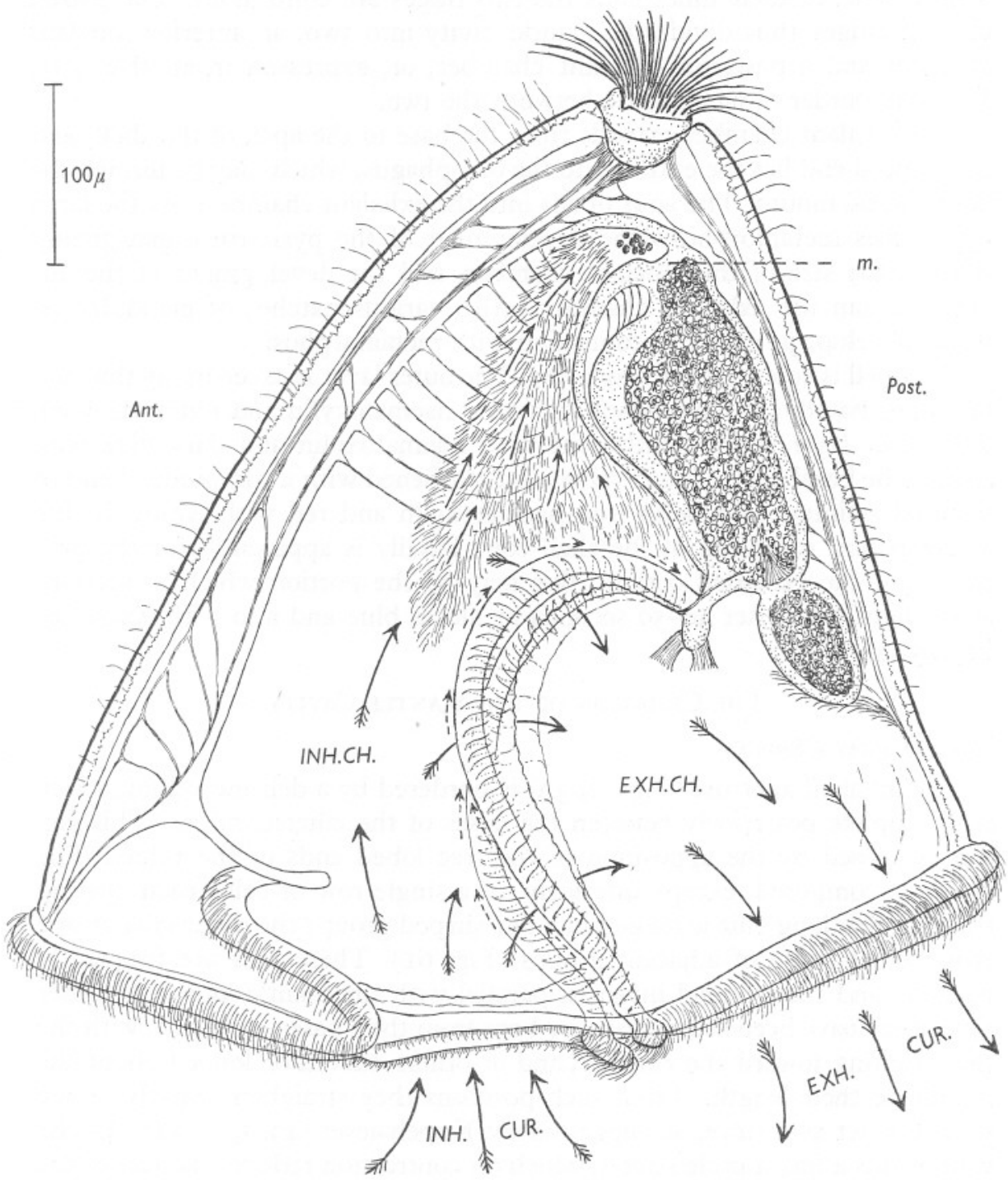

Fig. I. Membranipora membranacea (L.): young cyphonautes larva, to show the direction of the main water current (barbed arrows), of the food currents of the frontal surfaces of the ciliated ridges (small broken arrows) and of the ciliated funnel (small unbroken arrows). The metachronal waves of the lateral cilia of the ridges are indicated. Certain muscles are shown. INH.CH. and EXH.CH., inhalant and exhalant chambers. INH.CUR. and EXH.CUR., inhalant and exhalant currents; $m$, position of oesophageal mouth. 
mantle wall: at their inner ends the two ridges are continuous. The paired ciliated ridges thus divide the mantle cavity into two, an anterior inhalant chamber and a posterior exhalant chamber, or, expressed in another way, form the border of an aperture between the two.

The inhalant chamber extends from the base to the apex of the shell, and at its apical end lies the entrance to the oesophagus, which may be termed the oesophageal mouth. The anus opens into the exhalant chamber. As the larva approaches metamorphosis the development of the pyriform organ greatly reduces the size of the inhalant chamber, and the development of the adhesive organ the exhalant chamber. Also various patches of glandular (?) tissue develop, probably in connexion with metamorphosis.

The shell is composed of two layers. The outer layer is exceedingly thin and fades out basally; it stains black with iron haematoxylin and red with Azan. The inner layer stains faintly with iron haematoxylin and dark blue with Azan. The basal edge of each valve is strengthened with a continuous band of material staining black with iron haematoxylin and red with Azan. In life a transparent extension of the shell edge basally is apparently for the protection of the extended corona; this may be the portion which in sections stains light blue after 40-50 seconds in alcian blue and also with Azan (see Figs. 3, 4).

\section{The Ciliation of the Mantle Cavity}

\section{The Inhalant Chamber}

The inhalant aperture (Figs. 2, 3A) is bordered by a delicate velum, which is incomplete posteriorly between the bases of the ciliated ridges. This gap can be closed by the apposition of the free lobed ends of the ridges. The velum is composed, except anteriorly, of a single row of cells, each bearing about fifteen long cilia arranged in a fan-shaped group; the outer cilia of one group cross those of adjacent groups (Fig. 6E). These cilia are frequently inactive, and then extend inwards, parallel with the mantle lobes. At other times they have been seen stationary bent from their bases outwards, with the tips pointing toward the exterior, and at others curved or looped about the middle of their length. From such positions they straighten rapidly. They probably act as a sieve, as suggested by Kupelwieser (I905, p. 23). In the velum runs a fine muscle strand, which on contraction reduces the size of the inhalant aperture, the large ciliated cells becoming corrugated. The velar muscles are continuous posteriorly with the longitudinal muscles of the suspensory membranes of the ciliated ridges, while it would appear that anteriorly fibres are given off which are inserted on the pyriform organ. The appearance of the velum where it adjoins the pyriform organ is shown in Fig. 3 B, part of a section passing through the extreme posterior region of the anterior portion of the corona, where the ciliated bands turn inward to run across the ventral face of the larva. Kupelwieser (I905-6, p. 23, text-fig. 7) 
considered it probable that the velum of Cyphonautes compressus inclined outward when relaxed. In the larva of Membranipora membranacea it is reflected inward when relaxed, as may be seen in life, and in this position would be likely to interfere less with the ingoing current than in the position suggested by Kupelwieser.

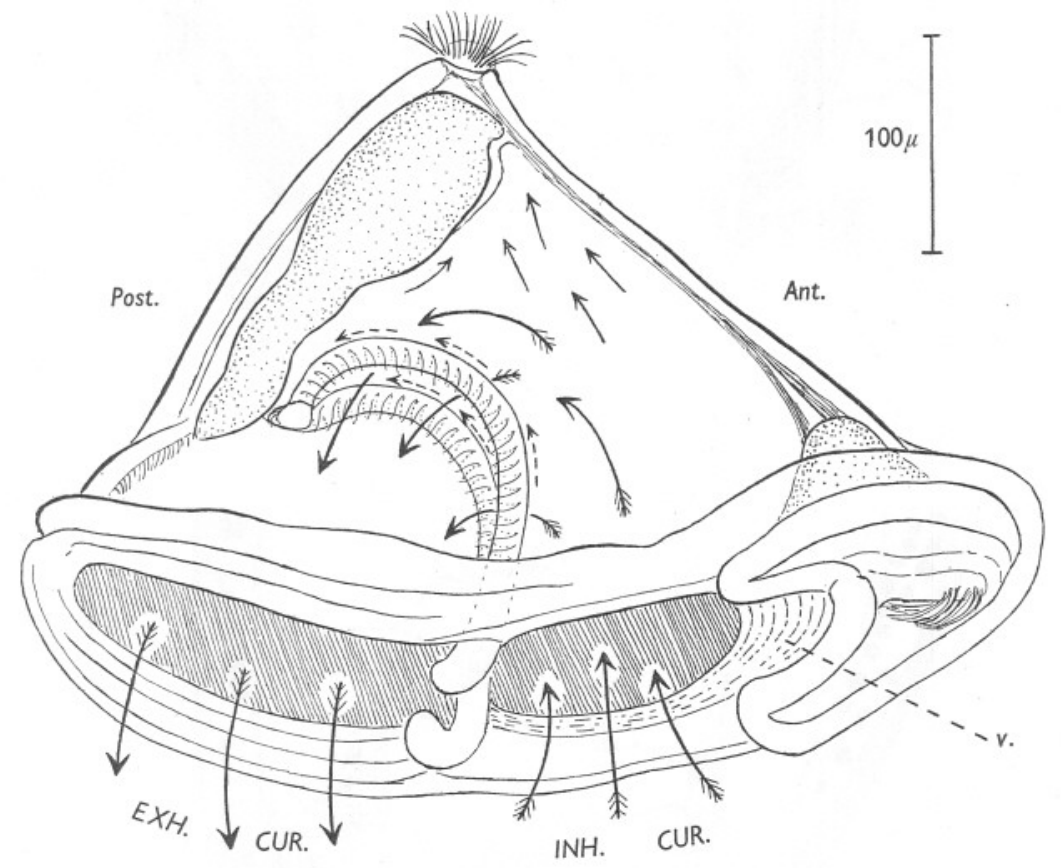

Fig. 2. Electra pilosa L.: cyphonautes larva (with pyriform organ well developed, but before the development of the adhesive organ), to show the inhalant and exhalant apertures. INH.CUR. and EXH.CUR., inhalant and exhalant currents; v., velum. Arrows as in Fig. I. Cilia mostly not shown.

At the base of the velum is a ridge of a single row of cells bearing long, coarse cilia (Fig. 3, c). These cilia appear active only when stimulated. When at rest they lie with their tips directed anteriorly; their effective stroke is toward the base of the ciliated ridges and they probably function in directing food organisms toward these.

Externally the inhalant aperture is bordered by the much reduced corona (Fig. 3A, r.c.), the short cilia of which partake of the activity of the fully developed anterior and posterior portions of the corona and have the same type of metachronal wave, the wave passing uninterruptedly over this region.

The upper part of the inhalant chamber has the form of a highly muscular and ciliated funnel leading to the oesophageal mouth (Fig. I). Circular muscles are present in its walls and occasionally when the lowest ring only is contracted, 

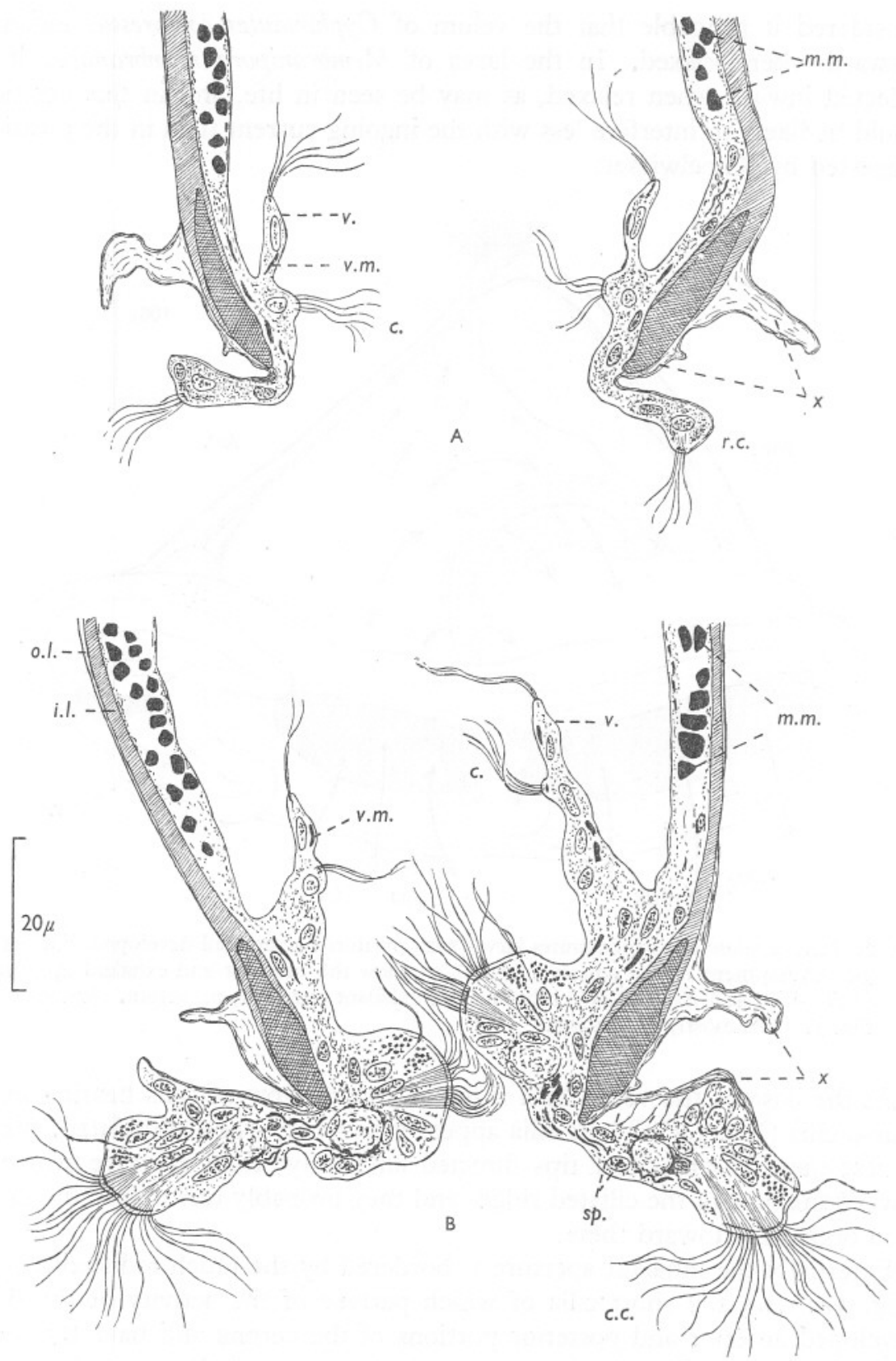

Fig. 3. Membranipora membranacea (L.): cyphonautes larva. A: section passing through the inhalant aperture to show the velum (v.) and the reduced coronal cells (r.c.). The velum is in the relaxed position. B: section passing through the anterior region of the velum (v.) near the extreme posterior part of the pyriform organ. The recurving of the corona makes it appear double on each side. c., cilia of the ridge at the base of the velum; c.c., cilia of the corona; i.l., inner layer of shell; m.m., mantle muscles; o.l., outer layer of shell; r.c., reduced coronal cells; sp., spaces due to shrinkage; v., velum; v.m., velar muscle; $x$, region of shell staining light blue with alcian blue and with Azan. The inner layer of the shell is shown hatched and the strengthening band cross-hatched. Heidenhain's iron haematoxylin and alcian blue. 
acting as a sphincter, the funnel momentarily has the appearance of an oesophageal or pharyngeal funnel, as remarked by Claparède (1863, p. I07, and pl. I8, fig. I5). In life when fully expanded the 'oesophagus' or 'pharynx' passes indistinguishably into the main part of the inhalant chamber. Contractions of the circular muscles of the funnel appear to occur only when the animal is irritated by the entry into the inhalant chamber of large food organisms, for instance peridinians.

In the cyphonautes of Electra pilosa long coarse cilia entirely clothe the funnel and extend well down toward the inhalant aperture. In the cyphonautes of Membranipora membranacea the posterior half only of the funnel is ciliated and the ciliation extends as a gradually narrowing tract to a point about half-way down the inhalant chamber (Fig. I).

The cilia of the funnel may be divided into three regions according to their activity: (I) an outer area over which the cilia are generally inactive unless the larva is feeding, (2) a middle area over which cilia are active at short intervals, and (3) a small inner area over which cilia appear generally active. Immediately in front of the sphincter guarding the entrance to the oesophagus is an unciliated area where food organisms collect before being swallowed or rejected.

\section{The Exhalant Chamber}

In the larva of Electra pilosa some scattered ciliation is present at the apex of the exhalant chamber and along the base of the suspensory membrane of the ciliated ridges. These cilia are not continuously active. The mantle cilia of the exhalant chamber are not as long as those of the inhalant chamber. In this larva a broad tract of cilia leads from the anus to the mantle edge: the cilia are generally active.

In the larva of Membranipora membranacea the exhalant chamber appears to be unciliated, except for cilia clothing the outer surface of the rectum, near the anus. These cilia are fully active only when a faecal pellet is being expelled. Their position of rest is at the beginning of the effective stroke.

The exhalant aperture is bordered by the posterior portion of the corona (Fig. 4), the cilia of which beat from the direction of the apex of the shell toward its base.

Glandular cells of the corona described and figured by Kupelwieser (I905-6, p. 5 ; pl. IV, figs. I7, I8) for the larva of Electra pilosa fixed in Flemming's and Hermann's solutions, were absent in my sections of the larva of Membranipora membranacea. It may be that such glandular cells are only present in late larvae ready to metamorphose, or it may be a specific difference, or perhaps the fixative used (see p. 45I) may have dissolved the contents. 

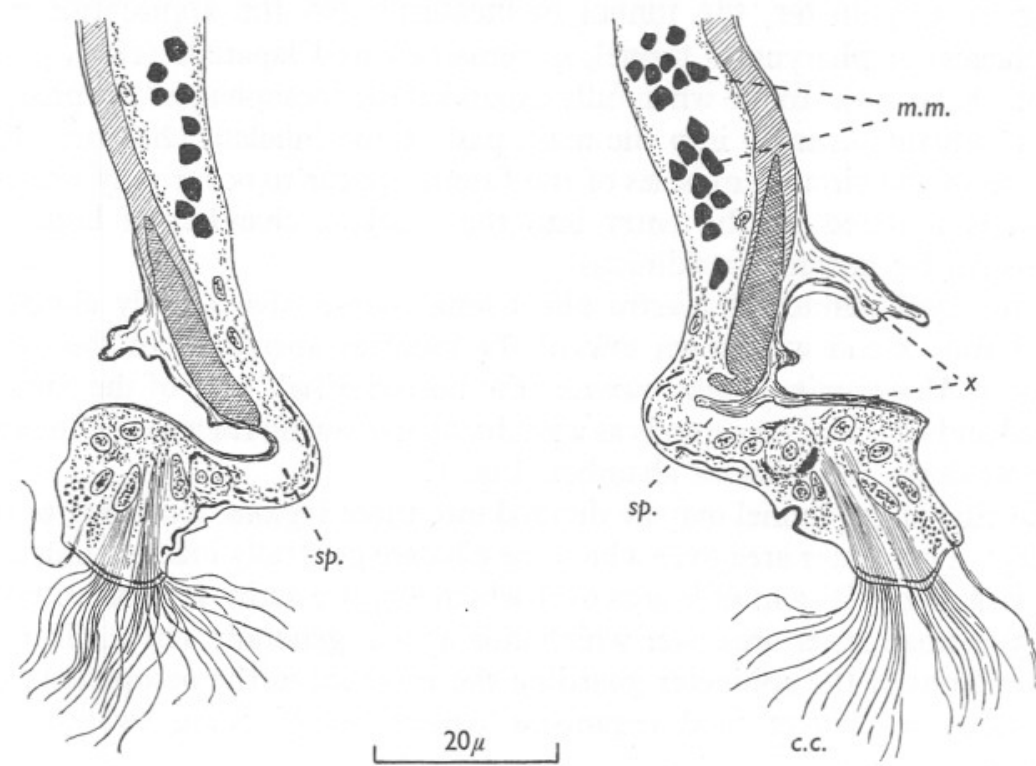

Fig. 4. Membranipora membranacea (L.): cyphonautes larva. Section passing through the exhalant aperture. c.c., cilia of the corona; m.m., mantle muscles; sp., space due to shrinkage; $x$., region of shell staining light blue with alcian blue and with Azan. The inner layer of the shell is shown hatched and the strengthening band cross-hatched. Heidenhain's iron haematoxylin and alcian blue.

\section{The Structure of the Ciliated Ridges separating the Inhalant and Exhalant Chambers}

The ciliated region of the ridges is suspended from the pallial lobes by a narrow, delicate, mobile membrane, which becomes contracted on fixation. Along the base of the suspensory membrane runs a muscle strand, which distally is continuous with the velar muscle. Proximally it is inserted on the body wall near the stomach (Fig. I). At some little distance from its insertion a short branch is given off, which loops round the shell adductor muscle (Fig. $5 \mathrm{~B}$ ). From the longitudinal muscle of the suspensory membrane fine fibres run transversely into the ridges (Fig. I). In each ciliated ridge is a fine longitudinal muscle fibre (Fig. 6A, l.m.r.). The muscular systems of the ciliated ridges, velum, pyriform organ and the adductor muscle are closely connected. The relation of the inner ends of the ciliated ridges to one another and to the shell adductor, before the development of the adhesive organ, is shown in Fig. 5 B.

Seen in the living larva, the two curved ciliated ridges have much the appearance of narrow gill filaments, but lateral, current-producing cilia are present on the inner surface only. 
On the ridges the ciliated cells are in three tracts, a frontal, a latero-frontal and a lateral (Fig. 6A). This ciliation is continued on to the free, lobed extensions of the ridges and these have a tract of latero-frontal and of lateral cilia on their outer as well as on their inner surfaces. No mucous glands could be distinguished in connexion with the ciliated tracts on the ridges: a group of large clear cells is present in the free lobed ends of the ridges, but these did not become blue when the larvae were placed in water tinted with methylene blue. In sections, spherules staining heavily with iron haematoxylin are arranged peripherally in these cells.
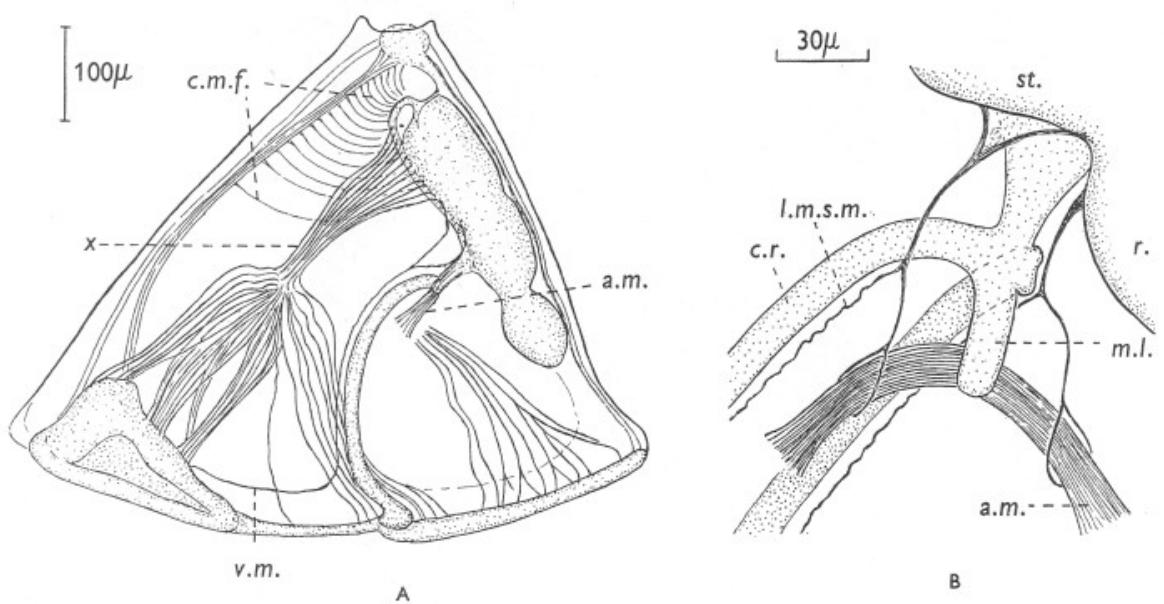

Fig. 5. Membranipora membranacea (L.): cyphonautes larva. A: the chief muscles of one mantle lobe as seen immediately after fixation in the fixative given on p. $45 \mathrm{I}$. B: sketch to show the relation of the ciliated ridges and their muscles to the shell adductor muscle, as seen in life. a.m., adductor muscle of the shell; c.m.f., circular muscles of the ciliated funnel; c.r., ciliated ridge; l.m.s.m., longitudinal muscle of the suspensory membrane; m.l., muscular loop connecting the adductor muscle to the body wall over the stomach; r., rectum; st., stomach; v.m., velar muscle, which continues as the longitudinal muscle of the suspensory membrane; $x$, muscle, which on contraction drags the mouth region down toward the ciliated ridges.

(I) Frontal cilia. The frontal cilia are long and coarse, and are borne on a single row of large cells. They occur in a group across the inner or apical end of each cell (Fig. 6B). These cilia appear active only when stimulated by the presence, in the inhalant current, of food organisms, which they send toward the inner ends of the ridges and the mouth. When at rest they lie with the tips directed toward the outer ends of the ridges, their position of rest being at the beginning of the effective stroke. When not actively beating they yet sometimes have a slight vibratory movement.

(2) Latero-frontal cilia. These long and rather stout cilia are latero-frontal in position and, although differing from those of bivalves in the direction of their beat, for convenience will here be termed latero-frontal cilia. They 
occur to the inner side of the frontal cilia and separated from the lateral cilia by an unciliated space. When at rest they are almost straight. They are about 20-30 $\mu$ long and $3.5 \mu$ apart in the larva of $M$. membranacea. Only the tips appear to bend during the beat, which is slow, with the effective stroke away from the frontal and toward the lateral cilia. This direction was unexpected, but careful focusing at a magnification of 1360 diameters confirmed it. These
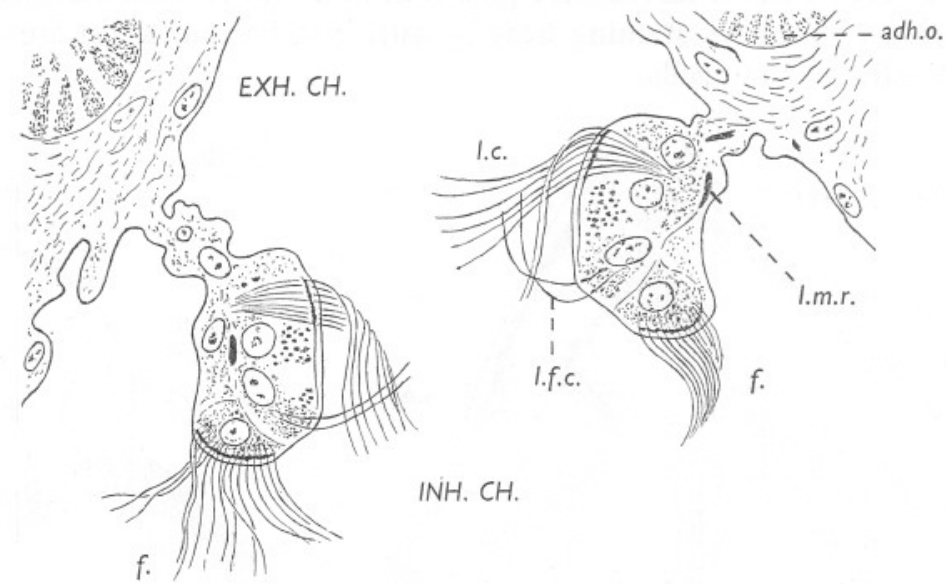

INH. CH.

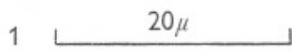

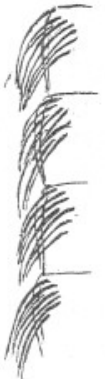

B

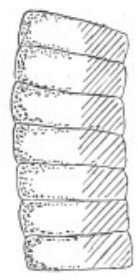

c

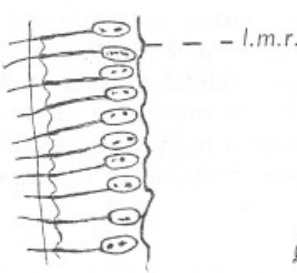

D

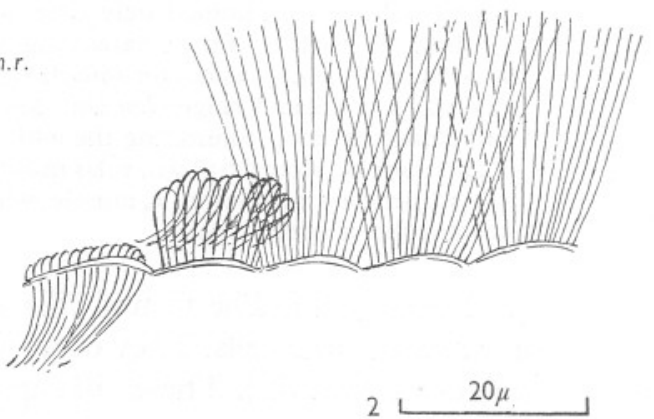

E

Fig. 6. Membranipora membranacea (L.): cyphonautes larva. A: transverse section through the ciliated ridges near their inner ends, in a specimen with well-developed adhesive organ (adh.o.). B: frontal cells in side view (living). c: lateral cells in surface view (living). The oblique rows of basal granules are indicated. D: latero-frontal cells in a section in a plane perpendicular to that of the beat. $\mathrm{E}$ : fan-shaped groups of cilia on the velum (living). f., frontal cilia; l.c., lateral cilia; l.f.c., latero-frontal cilia; l.m.r., longitudinal muscle of the ciliated ridge. INH.CH. and EXH.CH., inhalant and exhalant chambers. A and D, Heidenhain's iron haematoxylin. A and D to scale I; B, C and E to scale 2 . 
cilia probably form, to some extent, a grid between the inhalant and exhalant chambers, and, depending on movements of the suspensory membranes of the ridges, may project into the inhalant chamber, or across the aperture between the two. They are borne on a row of small, narrow, rectangular cells with their length across the length of the ridge. There is probably one cilium to a cell (Fig. 6D). The cilia appear to be arranged alternately, one being inclined at a lesser angle to the lateral surface than the next. In sections two diverging ciliary rootlets are very evident (Fig. 6A), but the fibres which proceed from these appear to form one cilium in life. Kupelwieser (1905, p. 23), however, considered that there were two cilia to a cell and that their function was sensory. He compared these ciliated cells with similar, but less developed, ciliated cells of the corona.

(3) Lateral cilia. The lateral ciliated cells occur in a single row on the inner surfaces of the ridges. The cells are rectangular with their length transverse to that of the ciliated ridges. The cilia are borne on the abfrontal half of the surface of the cell. The basal granules are arranged in oblique rows (seen living at a magnification of 1360 diameters) (Fig. 6C), as are those of the lateral cilia of lamellibranchs (Atkins, 1938, p. 332).

The cilia are long and beat across the length of the ridge, from the inhalant toward the exhalant chamber. They produce the main water current. The metachronal wave is that characteristic of lateral, current-producing cilia: it runs at right angles to the direction of beat, and passes up the left ridge and down the right one. The waves are laeoplectic, according to the nomenclature employed by Knight-Jones (1954, p. 504).

When at rest the cilia are wrapped across the ridge with the tips projecting beyond the frontal edge: their position of rest is at the beginning of the effective stroke.

The lateral cilia suffer intermissions which are independent of stoppage of the coronal cilia. When two or three drops of $7 \%$ magnesium chloride in tap water are added to a watch-glass in which the larvae are swimming, intermissions of the lateral cilia cease. Magnesium chloride does not appear to affect the action of the frontal, latero-frontal or mantle cilia.

\section{The Mode of Feeding}

Water, with contained food particles, is drawn into the inhalant chamber by the action of the lateral cilia on the ciliated ridges, and passes between the ridges into the exhalant chamber, leaving by the exhalant aperture (Figs. I, 2).

When the larva is not feeding the funnel cilia are mostly inactive, as are also the frontal cilia of the ridges, and many food organisms pass through into the exhalant chamber and out through the aperture. The ciliated ridges can be separated, allowing this to occur. It is doubtful to what extent the laterofrontal cilia act as strainers, since the direction of their beat is toward the exhalant chamber, although it appears that little more than their tips bend. 
When the larva is feeding the frontal cilia are active and food organisms travel up the ridges. From the inner ends of these they are conveyed over the ciliated tract of the funnel to the unciliated area in front of the oesophageal mouth. The cilia of this tract are long and powerful and some organisms in the anterior stream of the inhalant current pass directly on to this tract, without travelling up the ridges.

Organisms arriving at the oesophageal mouth are either swallowed singly or in small collections according to size, for instance Peridinium troichoideum, $20-30 \mu$ in diameter, is swallowed individually, while Chlorella stigmatophora, $2 \cdot 5-4.5 \mu$ in diameter, is taken in small collections. These organisms were used merely to demonstrate the currents and it is not known whether the cyphonautes larva is able to digest them.

The inhalant and exhalant currents are occasionally reversed, food organisms, and at times a faecal pellet, passing from exhalant to inhalant chamber and out through the aperture. This reversal is possibly due to contraction of the shell adductor, and of muscles of the upper part of the mantle, approximating the valves and forcing water from the exhalant to the inhalant chamber. It has been observed to occur during stoppage of the lateral cilia. Reversal of the beat of the lateral cilia was not seen.

Methods resorted to by the cyphonautes whereby unwanted material is rejected are as follows. When the gut is full and no more food can be accepted, or when distasteful material arrives at the mouth, the oesophageal valve remains closed. Rejection is effected by the funnel cilia ceasing to beatexcept for those over a small area in front of the mouth, which are generally active-then organisms already collected before the mouth, stream downwards, caught in the water current set up by the lateral cilia, and pass between the apical ends of the ridges into the exhalant chamber. Rejection may be assisted by the mouth region being dragged downward toward the ciliated ridges by contraction of muscles running from the body wall, over the anterior region of the stomach, to the mantle lobe about the middle of the inhalant chamber. These muscles are shown in Fig. $5 \mathrm{~A}$ at $x$.

Ehrenberg (1838, p. 395 and pl. 44, fig. 2), who first described the cyphonautes, demonstrated, by means of indigo in the surrounding water, the passage of material through the vestibule to the mouth and then through the gut and out at the exhalant aperture. Claparède (I863, p. I08) also observed this current, but apparently neither of them noticed one passing between the ciliated ridges, nor did Robertson (1908). Robertson (p. 273) ascribed to the action of the cilia of the oral atrium (funnel) the current setting toward the mouth. Kupelwieser (1905, pp. I7, 26) attributed to the pyriform organ with its ciliated groove and plume the function of conveying particles into the median atrium (inhalant chamber). $\mathrm{He}$ (p. 26) mentioned the occasional passage of small particles from one atrium to the other, between the ciliated ridges. 


\section{The Digestive System}

The digestive system is simple. The gut appears to be entirely ciliated, except for the valve at the entrance to the oesophagus (Fig. 7A). This valve is closed by a sphincter of striated muscle fibres. Muscle strands run between the valve and the stomach (Fig. 7B), and also between it and the mantle. The oesophagus is short: it is surrounded by a layer of strong circular muscle fibres (Fig. 7 C). There appear to be no muscle fibres surrounding the stomach, intestine or rectum, but muscles pass between the gut and the mantle (Fig. I). The stomach gradually decreases in diameter and passes imperceptibly into the intestine. There is little or no difference in the appearance of the epithelial lining of the two regions. A ventral tract of glandular or secretory cells, the contents of which stain darkly with iron haematoxylin, stretches from the anterior region of the stomach almost to the posterior end of the intestine. The tract is widest near the entrance of the oesophagus. The cells of the side walls of the stomach are particularly deep and contain many inclusions, which in life are yellow and brownish in colour. Similar inclusions are present in the less deep intestinal cells. In sections stained with iron haematoxylin the contents of the cells appear vacuolated, many of the vacuoles having faintly staining inclusions; both vacuoles and inclusions increase in size toward the bases of the cells. These cells are probably digestive in function (Fig. 7 D, E).

The cilia on both sides of the constriction separating intestine from rectum are long, particularly a ring of intestinal cilia which form a long tuft or plume projecting into the intestine (Fig. $7 \mathrm{H}$ ). From their appearance in crosssection (Fig. 7F) it would appear that the latter have a spiral or rotatory movement. They possibly function in forming faecal matter into a cord, or, together with the adjacent long rectal cilia, in passing it into the rectum. Especially common in the anterior region of the rectum are gland cells with darkly staining contents, which presumably form the transparent coat surrounding the faecal pellets. The greater length of the rectum is lined with an epithelium, the cells of which bear a coat of dense short cilia, and contain many vacuoles showing inclusions, which are possibly excretory (Fig. $7 \mathrm{G}$ ). In sections an anal sphincter could be distinguished, but not one at the constriction between intestine and rectum, although one probably exists.

Alcian blue, after about $40 \mathrm{sec}$., does not stain the free border of the gut cells, including those of the oesophageal valve, but does stain brightly the free border of the cells of the mantle cavity or vestibule, including those of the region immediately in front of the oesophageal valve (Fig. 7A).

The exact manner in which food, which has collected in the unciliated region in front of the oesophageal valve, is taken into the oesophagus could not be followed, the movement being very rapid. There appeared to be a momentary protrusion of the valve region and sometimes contraction of muscles of the ciliated funnel. Although the gut is entirely ciliated, movement 


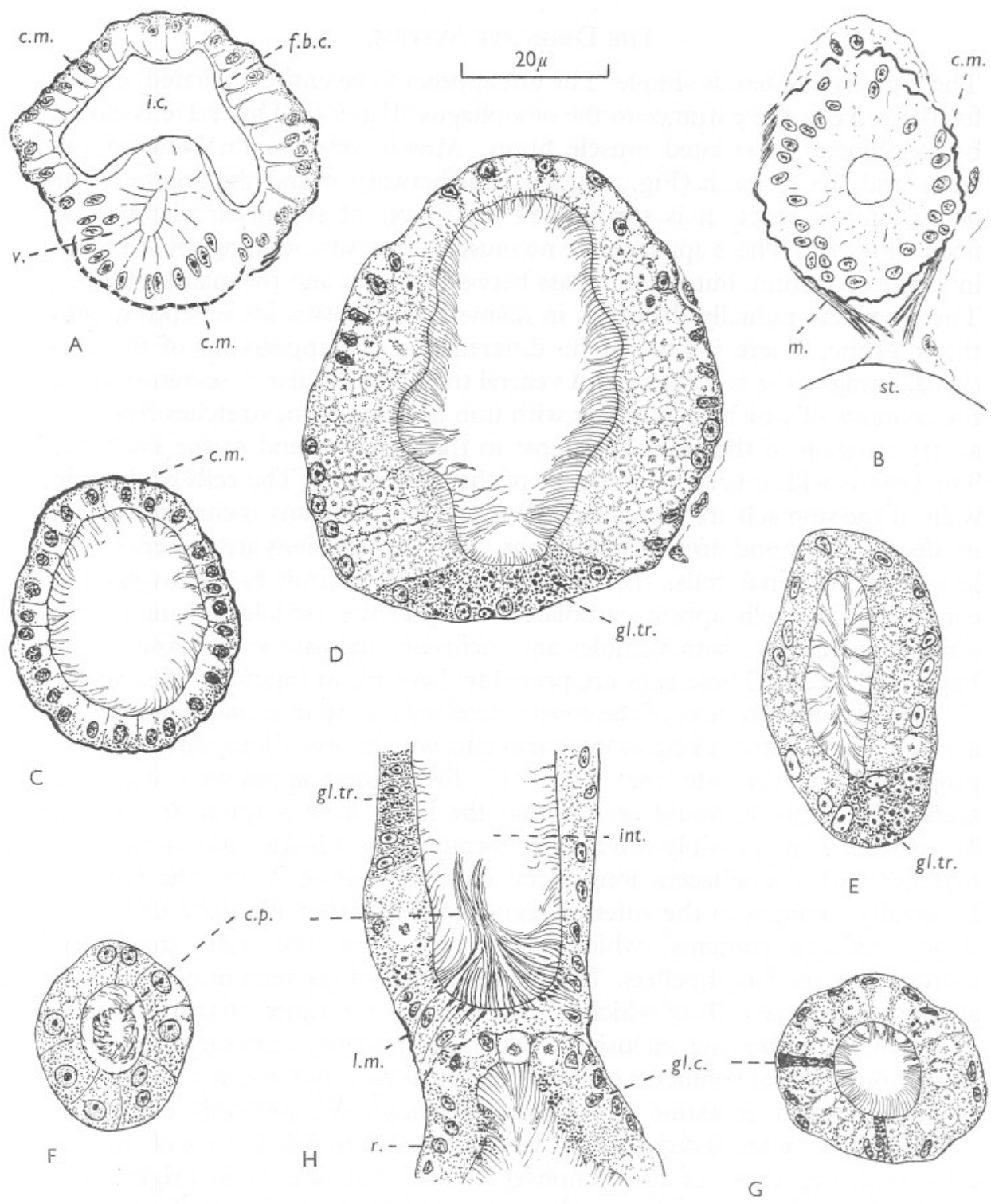

Fig. 7. Membranipora membranacea (L.): cyphonautes larva. A: section through the unciliated oral end of the inhalant chamber and obliquely through the valve (v.) leading to the oesophagus. Transverse sections of: $\mathrm{B}$, the oesophageal valve; $\mathrm{C}$, the oesophagus; $\mathrm{D}$, the stomach; E, the upper region of the intestine; F, the lower region of the intestine, showing the ciliary plume (c.p.) cut across; G, the middle region of the rectum, with short cilia; $\mathrm{H}$, longitudinal section through the constriction between the intestine (int.) and the rectum $(r$.$) , showing the long ciliary plume of the intestine, and the upper part of the$ rectum with gland cells and long cilia; c.m., circular muscle fibres; c.p., ciliary plume; f.b.c., free border of cells which stains bright blue with alcian blue; gl.c., gland cells; gl.tr., glandular tract of stomach and intestine; i.c., inhalant chamber; int., intestine; l.m., longitudinal muscle fibres; $m$., muscle fibres passing between oesophageal valve and stomach wall; r., rectum; st., stomach; v., oesophageal valve. Heidenhain's iron haematoxylin and alcian blue. 
of food within it was rarely seen. Long cilia were visible, but appeared motionless. Exceptionally, in one larva of Electra pilosa, an active stirring was seen of many Chlorella forming the contents of the stomach.

When a cyphonautes larva is placed in water containing many Peridinium trochoideum, the gut becomes tightly packed with them, and faecal pellets are expelled with the peridinians almost unchanged, but bound together by mucus. It would appear that under these conditions, the peridinians are forced through the gut so rapidly that the digestive enzymes have not sufficient time in which to act. Or it may be that the cyphonautes is unable to digest peridinians, which are heavily armoured with plates, thought to consist mainly of cellulose. The gut may become so filled with Peridinium and Chlorella that no division is visible between intestine and rectum, then just before defaecation a constriction appears between the two regions. Devèze (I953) has recorded the feeding of the cyphonautes of Electra pilosa on micro-organisms less than $0.9 \mu$ in diameter, but the larvae of both E. pilosa and Membranipora membranacea can certainly swallow organisms up to at least $30 \mu$ in diameter.

\section{The Swimming of Cyphonautes}

The ciliated corona is the locomotive organ of the larva. The metachronal wave of these cilia passes round the corona in a clockwise direction when the larva is viewed from above, travelling without a break over the much reduced cilia of the middle region or inhalent aperture. The larva swims with the apical organ foremost: frequently it swims in a vertical position. Sometimes, while in an upright position, it will maintain itself at the same level, going around very slowly in a circle, clockwise, that is in the same direction as the metachronal wave, and swaying exceedingly slightly from side to side, the coronal cilia, meanwhile, beating with a perfect metachronal rhythm. On occasions the level was maintained so closely that the larva remained in focus for minutes on end when viewed at a magnification of I I 5 diameters. Suddenly the valves would contract, the coronal cilia stop beating and the larva drop: it may do this without apparent cause or when touched by another organism.

The larva probably changes direction when swimming by protruding or withdrawing part of the corona, or possibly by protruding the pyriform organ with its vibratile plume.

The work recorded in this paper forms part of a study of ciliary feeding mechanisms undertaken while holding a Leverhulme Research Fellowship.

\section{SUMMARY}

The cyphonautes larva obtains its food by maintaining a continuous current of water through the mantle cavity, which is divided into inhalant and exhalant chambers, separated by the paired ciliated ridges. The water current is 
produced by lateral cilia on the ridges, on which there are also frontal, foodconveying, cilia. Food organisms travel from the inner ends of the ciliated ridges over the ciliated tract of the funnel of the inhalant chamber to the mouth.

Rejection of unwanted material is effected by the mouth remaining closed, while material in front of it is carried off in the current passing into the exhalant chamber, most of the funnel cilia meanwhile remaining inactive. Rejection is assisted on occasions by the mouth region being dragged downward toward the ciliated ridges by contraction of certain muscles in the mantle.

The alimentary system is simple. The mouth, closed by a sphincter, leads into a short oesophagus and this in turn into the stomach, which passes imperceptibly into the intestine. A constriction generally separates the intestine from the rectum. Notes are given on the histology of the gut.

Observations on swimming of the larva are given.

\section{REFERENCES}

Atkins, D., I938. On the ciliary mechanisms and interrelationships of lamellibranchs. Pt. VI. Quart. F. micr. Sci., Vol. 80, pp. 33I-44.

- I955. The cyphonautes larvae of the Plymouth area and the metamorphosis of Membranipora membranacea (L.). F. Mar. biol. Ass. U.K., Vol. 34, pp. 44I-9.

ClaparÈde, A. R. E., 1863. Beobachtungen über Anatomie und Entwicklungsgeschichte Wirbelloser Thiere an der Küste von Normandie Angestellt. Leipzig.

DevÈze, L., I953. Contribution à l'étude de la nutrition des stades larvaires planctoniques. I. Rec. Trav. Sta. Mar. Endoume, Fasc. 8, pp. 49-54.

EhrenberG, C. G., 1838. Die Infusionsthierchen als Vollkommene Organismen. Leipzig. 2 vols.

KNIGHT-Jones, E. W., I954. Relations between metachronism and the direction of ciliary beat in Metazoa. Quart. F. micro. Sci., Vol. 95, pp. 503-2I.

KuPELWIESER, H., I905-6. Untersuchungen über den feineren Bau und die Metamorphose des Cyphonautes. Zoologica, Stuttgart. Heft 47 (=Bd. I9, Lfg. 4), pp. iv +50 .

Marcus, E., 1940. Mosdyr (Bryozóa eller Polyzóa) in Danmarks Fauna, Vol. 46, København.

Prouno, H., I892. Contribution à l'histoire des Bryozoaires. Arch. Zool. exp. gén., Ser. 2, T. I0, pp. 557-656.

ROBERTSON, A., I908. The incrusting chilostomatous Bryozoa of the west coast of North America. Calif. Univ. Publ., Zool., Vol. 4, pp. 253-344.

SCHNEIDER, A., I869. Zur Entwickelungsgeschichte und systematischen Stellung der Bryozoen und Gephyreen. Arch. mikr. Anat., Bd. 5, pp. 260-80. 